\title{
Mortality associated with OsHV-1 in spat Crassostrea gigas: role of wild- caught spat in the horizontal transmission of the disease
}

\author{
Lionel Degremont ${ }^{1, *}$, Abdellah Benabdelmouna ${ }^{1}$ \\ ${ }^{1}$ Ifremer, SG2M, LGPMM, Avenue Mus de Loup, 17390, La Tremblade, France \\ *: Corresponding author : Lionel Degremont, email address : lionel.degremont@ifremer.fr
}

\begin{abstract}
:
The French oyster production of Crassostrea gigas is based on two sources of spat: wild-caught (WC) and hatchery-produced (HP). Massive mortality related to the ostreid herpesvirus type 1 (OsHV-1) has affected both sources in France since 2008. We investigated the mortality in juvenile $C$. gigas due to the horizontal transmission of OsHV-1 within (separated condition) and between (mixed condition) the two spat sources in three environments from April to June 2010. In the separated condition, no mortality was observed in the HP batches, while the WC batches experienced moderate to high mortality $(40-80 \%)$. In contrast, the WC and HP batches experienced high mortality in all tested environments for the mixed condition. At the beginning of the trial, the HP batches were all negative for OsHV-1 DNA detection by real-time PCR, while the WC batches were all positive for OsHV-1 DNA detection by real-time PCR, even though the percentage of virus DNA-positive oysters and viral load were low. During the experiment, all batches that exhibited mortality were positive for OsHV-1 with a high viral load, while OsHV-1 was never detected for the HP batches of the separated condition. Together, our results demonstrated that OsHV-1 was horizontally transmitted from the WC oysters to the HP oysters. Our study is the first to indicate that the mortality related to OsHV-1 in HP oysters can be avoided using ponds or tanks. However, these oysters were always protected from OsHV-1, and HP oysters could also experience mortality and spread the disease similar to the WC oysters if such care is not used. Finally, the persistence of OsHV-1 at a sub-clinical level in certain oysters supports the hypothesis that the virus can be reactivated and cause viral replication. The use of the two spat sources is discussed to better understand the spread of the disease among oyster stocks.
\end{abstract}

Keywords: Crassostrea gigas ; Wild-caught ; Hatchery-produced ; Spat ; Mortality ; Horizontal transmission ; Ostreid herpesvirus OsHV-1 


\section{INTRODUCTION}

The production of French Crassostrea gigas oysters is based on two sources of spat: wild-

43 caught spat, especially from Marennes-Oléron Bay and Arcachon Bay, which are both located

44 along the French Atlantic coast, and hatchery-produced spat from commercial hatcheries in

45 France. The amount of hatchery-produced spat has increased regularly each year, reaching nearly

463 billion spat units in 2012. The increasing demand for hatchery-produced oysters is primarily

47 driven by triploids. Moreover, the amount of wild-caught spat varies each year depending on

48 disease and environmental conditions, as larvae and juveniles are highly susceptible to the

49 Ostreid Herpesvirus type 1 (OsHV-1) (Le Deuff et al. 1994; Le Deuff et al. 1996; Renault et al.

50 2000; Dégremont 2011). Since 2008, disease investigations have revealed the involvement of

51 OsHV-1 in numerous cases of recurrent and massive mortality that have been reported in juvenile

52 C. gigas in Europe, Australia, New Zealand and on the western coast of the USA (EFSA 2010;

53 Segarra et al. 2010; Cameron and Crane, 2011; Garcia et al. 2011; Burge and Friedman 2012;

54 Lynch et al. 2012; Martenot et al. 2012; Peeler et al. 2012; Pernet et al. 2012; Roque et al. 2012;

55 Jenkins et al. 2013; Paul-Pont et al. 2013). Similar mortality is also expected in larvae in the wild

56 but has not yet been documented. To address the massive mortality related to OsHV-1, two

57 strategies have been developed to supply more spat to the French oyster industry. The first has

58 been initiated by hatcheries that develop a breeding program for OsHV-1-resistance in C. gigas

59 oysters, because this trait could be selected (Dégremont et al. 2010b; Dégremont 2011). The

60 second simply increases the number of spat produced by the commercial hatcheries or those

61 caught in the wild by oyster farmers who have increased the capacities for spat collection. The 
62 latter strategy results in more wild and unselected spat being caught, and this spat could 63 potentially be infected with OsHV-1.

64 The transfer of oysters between the growing areas has been stipulated as a major source of 65 disease transmission in France and throughout Europe. To better understand the oyster 66 production cycle in France, note that wild-caught spat settle on various substrates during the 67 summer, primarily along the Atlantic coasts. They are then detached the following winter and 68 spring and sold to the oyster farmers. This process involves numerous oyster transfers as the spat 69 are moved between growing areas (Goulletquer and Le Moine 2002). Meanwhile, hatchery70 produced oysters are available throughout the year, and most of them are maintained either in a 71 nursery or in field conditions before they are sold and then transferred between growing areas.

72 Spat from both sources are then capable of spreading pathogens if they are grown in a 73 contaminated area. Oysters can be produced in batches to prevent their exposure to the mortality 74 risk factors in a controlled environment in the hatchery and nursery, as described in Dégremont et 75 al. (2010b) and Dégremont (2011). These systems utilize UV filtration or seawater that has been 76 pumped away from the oyster leases and stored for a certain amount of time in ponds. Lastly, 77 transfers continue to occur throughout the life of the oysters as stocks are routinely moved within 78 the local field grow-out sites, with sites dedicated to spat, juveniles or adults, as well as among 79 coastal areas with numerous transfers of adults from Brittany or Normandy to the Charentais 80 Sounds and Marennes-Oléron Bay, where most of the oysters are grown in ponds before being 81 sold.

Every year since 2008, massive mortality outbreaks related to OsHV-1 have been 83 observed in $C$. gigas spat. The peak of the disease usually occurs as soon as the seawater 84 temperature exceeds $16^{\circ} \mathrm{C}$, and other mortality events related to OsHV-1 may still be observed in 
85 naïve juveniles when they are transferred to a contaminated area (Dégremont 2013). Therefore,

86 the disease reoccurs the next spring in the new generation of hatchery-produced and wild-caught

87 spat, regardless of the environmental conditions during the fall and winter, meaning that OsHV-1

88 remains persistent in asymptomatic C. gigas or other organisms, as also suggested by Arzul et al.

89 (2002) and Peeler et al. (2012).

90 Two approaches were developed to better characterize the risk for the natural transmission

91 of OsHV-1 among oyster stocks cultured in France: i) investigating the horizontal transmission of

92 OsHV-1 between naïve hatchery-produced oysters and adult oysters that survive a mortality

93 outbreak caused by the disease, as described in Dégremont et al. (2013), and ii) investigating the

94 transmission between wild-caught and naïve hatchery-produced spat. This study reports the 95 second approach. The primary objective of this study is to investigate the natural horizontal 96 transmission of OsHV-1 throughout cohabitation trials within and between the two sources of 97 spat using several batches per source in controlled conditions (laboratory) and in uncontrolled 98 environments (ponds and grow-out field).

\section{MATERIALS AND METHODS}

\section{Oyster batches}

Two batches of wild-caught spat were purchased from oyster farmers in March 2010. One 104 batch was from the Marennes-Oléron Bay, hereafter referred to as WC1, and the second one was

105 from the Arcachon Bay, hereafter referred to as WC2. In France, these two bays account for 
approximately $80 \%$ of the wild-caught production. The two batches were 9 months old, and no

107 data were available with regard to their life history, specifically their cumulative mortality at 108 reception.

Three hatchery-produced batches were used, including two diploids, hereafter referred to as HP1 and HP2, and one triploid, hereafter referred to as HP3. All of the HP batches were spawned at the Ifremer hatchery in La Tremblade in August 2009. For the diploid batches, the

112 parents were sampled in the Marennes-Oléron Bay, and 6 and 7 males were crossed with 19 and 11321 females to produce HP1 and HP2, respectively. For the triploid batch, the spermatozoa 114 produced by 14 tetraploid males from the broodstock maintained at the Ifremer hatchery and used 115 by the French commercial hatcheries to produce triploids, fertilized oocytes from the same 19 116 females used for HP1. The larvae were grown in 30-L tanks for 2-3 weeks. Competent larvae for 117 metamorphosis were then settled in 120-L tanks using cultch. When the spat reached 2 mm, they 118 were transferred to the Ifremer nursery in Bouin for intensive growth using raw seawater 119 enriched with Skeletonema costatum. Lastly, the three hatchery-produced batches were 120 transferred to La Tremblade for the survey, and any abnormal mortality was recorded from 121 spawning to the beginning of the survey. At the beginning of the experiment, the individual 122 weight of the oysters was similar among the five batches and was approximately $1 \mathrm{~g}$.

\section{Ploidy analyses}

The DNA ploidy level of the juveniles was determined using flow cytometry (FC) with DAPI (4,6-Diamidino-2-phenylindole) staining. For each batch, 100 spat were randomly sampled

127 and individually analyzed. The nuclei were extracted from small pieces $\left(1 \mathrm{~mm}^{2}\right)$ of gills, mixed 
128 with $2 \mu$ l of trout red blood cells (TRBC, Coulter DNA Reference Calibrator, 629972) as an

129 internal standard solution, and stained with DAPI at a concentration of $2 \mu \mathrm{g} / \mathrm{ml}$ in a 2-ml final

130 solution. FC was performed on a PA II flow cytometer (Partec) with the following conditions:

131 excitation-100 W mercury lamp, UG 1 (290-410 nm, 3 mm), chromatic beam splitter (TK 420),

132 emission-beam splitter (TK 420, TK 560), and barrier filter (CG 455) for the DAPI signals. The

133 peak positions and the coefficients of variation (CV) were calculated automatically (PARTEC

134 PAS II software package). At least 2000 nuclei were analyzed from each sample. The ratio

135 between the fluorescence channels of the nuclei and the internal peaks is characteristic of the

136 DNA ploidy level, which is equal to 0.4 for diploids and 0.6 for triploids.

138 Experimental design

139 The experiment was conducted from April $1^{\text {st }} 2010$ to June $30^{\text {th }} 2010$. Three sites in La

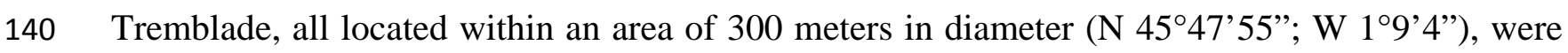
141 used for the survey: the Ifremer's laboratory, the Ifremer's ponds, and the field (Fig. 1). At each 142 site, two temperature probes (Progesplus, 59780 Willems, France) recorded the seawater 143 temperature every 30 minutes.

In the field, three bags per batch of 200 oysters each were attached to iron racks, which is 145 the cultural practice used by most French oyster farmers (Table 1). Numerous oyster leases 146 surround our experimental site.

In the ponds, each batch was grown alone in one pond with three bags containing 200 148 oysters each, which corresponds to the separated condition, i.e. the cohabitation trial among 149 oysters within the batch. Another pond received three hatchery-produced batches and the wild- 
150 caught batch WC1, which corresponds to the mixed condition, i.e. the cohabitation trial between 151 batches. Unfortunately, the WC2 batch could not be tested in the mixed condition due to the lack 152 of ponds. Three bags were used for the mixed condition, each containing four smaller bags of 50 153 oysters per batch, to obtain a total of 600 oysters in the pond as for the separated condition (Table 154 1). The ponds were naturally alimented by seawater during the spring tides when the tidal 155 coefficient exceeds 85. The average depth of each pond was approximately $70 \mathrm{~cm}$ for a volume 156 of $250 \mathrm{~m}^{3}$.

The WC2 batch was not tested in the laboratory due to the lack of space. Three 50-L tanks were used per batch for the separated condition, each containing 200 oysters. For the mixed 159 condition, three tanks containing 50 oysters per batch were used for the hatchery-produced 160 batches and the WC1 batch, as in the pond condition. Flow-through seawater enriched with 161 Skeletonema costatum was renewed hourly and constantly filtered and UV-treated to protect the 162 oysters from the external mortality risks factors, particularly OsHV-1. All tanks were carefully 163 cleaned twice per week.

Lastly, extreme care was used to avoid accidental contamination among the tanks or 165 among the ponds by changing gloves or waders between each tank or pond. Unfortunately, one 166 tank containing HP2 oysters was contaminated with the seawater of another tank containing WC1 167 oysters on April $30^{\text {th }}$, while abnormal mortality was recorded for the WC1 oysters. The HP2 168 oysters in this tank exhibited high mortality a few days later (90\%) and were excluded from the 169 studies. 
Dead and live oysters were counted once per week in the laboratory and pond conditions

173 and every two weeks in the field condition until the end of the experiment on June 30th. Dead 174 oysters were not removed, except for those sampled for the disease diagnoses.

\section{OsHV-1 DNA detection and quantification}

Since 2008, the disease diagnoses revealed that most of the mortality outbreaks reported

178 in spat C. gigas are due to OsHV-1, and no other relevant pathogens were found (Guichard et al. 179 2011). Although Vibrio splendidus could be associated with mortality events in C. gigas (Lacoste 180 et al. 2001; Le Roux et al. 2002), routine tools to discriminate virulent from non-virulent strains 181 of $V$. splendidus are lacking. Furthermore, $V$. splendidus is more likely to be ubiquitous because 182 correlations between the mortality and the presence or the bacterial load of $V$. splendidus were 183 weak, negative and not significant in contrast to OsHV-1 during a mortality outbreak in juvenile 184 C. gigas (Dégremont, 2011). Therefore, this research only examined OsHV-1 DNA.

At the beginning of the experiment, 50 oysters per batch were sampled for OsHV-1 detection and quantification. Additionally, 5 moribund oysters and 12 live oysters per batch, per site, and per condition were sampled during the mortality peaks and at the end of the experiment, 188 respectively.

The OsHV-1 DNA was detected and quantified in each sampled oyster using a highly sensitive real-time PCR technique developed by Pépin et al. (2008). Briefly, DNA was extracted

191 from 25 mg of fresh oyster tissue (mantle) using the QiagenQiamp® tissue mini kit, and 20 ng of 192 DNA was used for the real-time PCR (Stratagene) with the following conditions: initial 193 denaturation for $10 \mathrm{~min}$ at $95^{\circ} \mathrm{C}$, followed by 40 cycles of $95^{\circ} \mathrm{C}$ for $30 \mathrm{~s}, 60{ }^{\circ} \mathrm{C}$ for 1 min, and 
$19472{ }^{\circ} \mathrm{C}$ for $45 \mathrm{~s}$. The primer pairs used to detect the viral DNA were described in Webb et al. 195 (2007) for targeting the OsHV-1 DNA polymerase sequence. All results were expressed as the 196 viral DNA copy number per mg of oyster tissue.

\section{Statistical analyses}

The cumulative mortality on June $30^{\text {th }}$ was analyzed per site using the GENMOD 200 procedure SAS ${ }^{\circledR}$ software version 9 with a logit transformation and a binomial distribution. The 201 logistic regression models used were the following:

$202 \operatorname{Logit}(\mathrm{Y} i j)=\log (\mathrm{Y} i j /(1-\mathrm{Y} i j))=\mu+\operatorname{batch} i+$ condition $j+$ batch $i \mathrm{x}$ condition $j$

203 where Yij is the probability of an unfavorable response (dead for the mortality) in the laboratory 204 or the pond for the ith batch in the jth condition (mixed and separated), and $\mu$ is the intercept.

$205 \operatorname{Logit}(\mathrm{Y} i)=\log (\mathrm{Y} i /(1-\mathrm{Y} i))=\mu+$ batch $i$

206 where $\mathrm{Y} i$ is the probability of an unfavorable response in the field for the ith batch, and $\mu$ is the 207 intercept.

208 Multiple comparisons were conducted using the least squares means statement and the SLICE 209 option, which allows for the testing of the condition factor for each batch or the batch factor for 210 each condition when a significant interaction is found between both factors. Thus, the statistical 211 test is more powerful than rerunning the analysis within the batch because the degrees of freedom 212 are not reduced (Littell et al. 2002). 


\section{$214 \quad$ RESULTS}

\section{DNA ploidy determination}

217 FC measurements of the DNA ploidy level showed that all batches used in this study were 218 effectively of the expected DNA ploidy level. All wild-caught spat (WC1 and WC2), as well as 219 all spat from HP1 and HP2 were of the expected normal diploid ploidy levels. This characteristic 220 was evidenced by the single peak and a ratio of fluorescence of 0.4 , which is typical of diploid 221 nuclei. Similarly, all HP3 spat were triploid, as evidenced by the single triploid peak and a ratio 222 of fluorescence of 0.6.

\section{Seawater temperature}

The seawater temperatures at the three sites are shown in Fig. 2. The temperature ranged 226 from 11 to $15^{\circ} \mathrm{C}$ at the beginning of the experiment and reached 21 to $27^{\circ} \mathrm{C}$ at the end of June.

227 The seawater in the ponds was highly variable on April $22^{\text {nd }}$ or May $4^{\text {th }}$ due to the renewal of the 228 seawater, which only occurs during the spring tide, combined with the weather conditions due to 229 the small volume of the pond.

In the field, batches HP2 and WC1 were the first to exhibit mortality at a low level $233(<30 \%)$ in May. During the first two weeks of June, massive mortality was reported for all 
234 batches (Fig. 3). The mean mortality ( \pm standard deviation) on June $30^{\text {th }}$ was $67 \pm 14 \%$, ranging 235 from 52 to $88 \%$ (Table 2). A significant difference in the mortality among the batches was found $236(P<0.01)$, with the lowest mortality for the WC batches $(54 \%)$, intermediate mortality for HP1 237 and HP3 (70\%), and the highest mortality for HP2 (88\%).

In the pond, no abnormal mortality was reported for the three HP batches throughout the 239 experiment, while high mortality (39-82\%) occurred for the two WC batches for the separated 240 condition, primarily between April $29^{\text {th }}$ and May $12^{\text {th }}$ (Fig. 4a and Table 2). A major mortality 241 outbreak (94\%) was also observed during this period for all batches in the mixed condition (Fig. 242 4b). A significant interaction was found between the batches and the conditions ( $P=0.02)$. At the 243 batch level, the mortality was significantly higher for the mixed condition than for the separated 244 condition for all batches except for WC1 (Table 2). At the condition level, a significant difference 245 of mortality among the batches was only found for the separated condition $(P<0.01)$, with a 246 lower mortality for the HP batches. The mixed condition did not show significant differences $(P$ $247=0.67)$.

Similarly, same results were found in the laboratory. Mortality was primarily observed 249 during the first two weeks of May, but it only occurred for all replicates containing the WC1 for 250 the separated condition (Fig. 5a). For the mixed condition and the same period, only one tank 251 exhibited high mortality (81\%), ranging from 57\% for WC1 to $100 \%$ for HP2 (Fig. 5b). Because 252 mortality was not observed for the two tanks in the mixed condition, the mean mortality for this 253 condition dropped to $27 \%$, and the standard deviation within batches was high. The batches and 254 the condition showed a significant interaction $(P<0.0001)$. At the batch level, the mortality was 255 always significantly higher in the mixed condition than in the separated condition except for the 256 WC1. At the condition level, the mortality significantly differed among the batches of both 
257 conditions, with a higher mortality for the WC1 batch in the separated condition and lower 258 mortality for the WC1 batch in the mixed condition $(\mathrm{P}<0.0001)$ (Table 2).

260 OsHV-1 DNA detection and quantification

At deployment, OsHV-1 DNA was not detected in any of the 150 HP oysters screened on 262 April $1^{\text {st }}$, while $2 \%$ and $14 \%$ of the WC2 and WC1 oysters, respectively, were found to be 263 positive but contain a low viral load $\left(<10^{+4}\right.$ DNA copy per mg of fresh tissue)(Table 3$)$.

Irrespective of the site, condition or batch, all oysters sampled that were moribund during

265 the mortality event were positive for a very high viral load, exceeding $10^{+6}$ DNA copies per mg 266 of fresh oyster tissue.

At the endpoint, OsHV-1 was not detected in any of the HP batches for the separated 268 condition in the laboratory or the pond on June $30^{\text {th }}$ (Table 3 ). OsHV-1 was detected at a low 269 viral load in 8\% of the WC2 oysters in the pond as well as in 33\% of the HP3 and 9\% of the 270 WC1 in the mixed condition in the laboratory. Lastly, a low level of OsHV-1 $\left(<10^{+4}\right.$ DNA copies 271 per mg of fresh tissue) was also detected approximately 25\% of the oysters in all batches from the 272 field on June $30^{\text {th }}$.

\section{DISCUSSION}

275 The two types of spats (wild versus hatchery) used in this work were assumed to be 276 representative of their respective origin in France. WC1 and WC2 originated from the Arcachon 277 and Marennes-Oléron Bays, respectively, which account for $80 \%$ of the annual wild-caught spat 
278 production in France on average. Additionally, the C. gigas populations in France were not 279 genetically differentiated (Rohfritsch et al., 2013). Alternatively, diploid HP batches were 280 produced using genitors sampled in the Marennes-Oléron Bay, while triploids were produced 281 using tetraploid males from the same broodstock used by the French commercial hatcheries. The 282 incidence and the kinetics of the mortality, combined with the detection of high viral loads (> $28310^{+6}$ DNA copies per mg) in moribund oysters, strongly support that OsHV-1 was the main cause 284 of the mortality, as reported in previous studies (Pépin et al. 2008; Sauvage et al. 2009; Oden et 285 al. 2011; Dégremont et al. 2013). A high variation in mortality and in resistance to OsHV-1 is 286 common among C. gigas batches, as evidenced by Sauvage et al. (2009), Dégremont et al. 287 (2010c) and Dégremont (2011). This variation explains the variation in mortality observed 288 among the three HP batches in the present study in the field or in the mixed condition in the 289 laboratory (Figs. 3 and 5b). The main objective of this study was not to compare the HP batches, 290 but to study the horizontal transmission of OsHV-1 throughout cohabitation trials within batches 291 and between WC and HP batches.

Low and chronic mortality was observed in May for WC1 and HP2 in the field (Fig. 3). This result could be easily explained by the activation of the replication of OsHV-1, which 294 started as soon as the temperature reached approximately 14 to $16^{\circ} \mathrm{C}$, combined with a relatively 295 higher susceptibility of HP2 to viral infection compared to the other HP batches. The kinetics of 296 the mortality related to OsHV-1 according to the seawater temperature pattern agrees with the 297 results found in the cohabitation trial regarding transmission between infected adults and naïve 298 juvenile C. gigas (Dégremont et al. 2013). For instance, acute mortality was observed 10 to 12 299 days later when the temperature reached and remained above $16^{\circ} \mathrm{C}$, regardless of the site where 300 the oysters were grown (Fig. 2), supporting the important role of the seawater temperature in 
301

302

303

mortality related to OsHV-1 (Garcia et al. 2011). This value of the seawater temperature is in agreement with several studies that clearly showed the lower threshold of $16^{\circ} \mathrm{C}$, beyond which disease transmission and mortality related to OsHV-1 occur (Dégremont 2013; Dégremont et al. 2013; Petton et al. 2013). The mortality event lasted over two weeks, and no other mortality event was reported until the end of the experiment (Figs. 3, 4 and 5), which is characteristic of the OsHV-1 mortality pattern.

The major findings of this study concern the role of the origin of the batch, i.e. hatcheryproduced and wild-caught spat or contaminated and disease-free animals, on the transmission of the disease, as well as the possibility to grow oysters without mortality due to OsHV-1. At the beginning of the experiment, OsHV-1 was not detected in any of the 150 oysters screened among the three HP batches (diploids and triploids), which agrees with all of our OsHV-1 screening on HP oysters performed since 2009 (more than a 1000 individuals screened) (Dégremont 2011 \& 2013; Dégremont et al. 2013). In contrast, both WC batches were found to be infected with OsHV-1, even though the prevalence and viral load were low. This finding indicates that WC oysters were infected in their respective native areas, where mortality related to OsHV-1 usually occurs. Furthermore, this finding revealed a latent stage of the virus, as recently observed in adults (Dundon et al. 2011; Dégremont et al. 2013). With regard to the mortality events, no mortality was observed throughout the experiment when a HP batch was grown alone in a tank or in a pond (Figs 4a and 5a), suggesting that HP spat could be free of OsHV-1 and subsequently mortality-free if grown in a safe environment. However, such culture areas are limited due to the range expansion of the virus throughout Europe, the USA, New Zealand and Australia (EFSA 2010; Cameron and Crane, 2011; Garcia et al. 2011; Burge and Friedman 2012; Jenkins et al. 2013; Paul-Pont et al. 2013). This, the feasibility of this approach is questionable. Moreover, the 
324 Marennes-Oléron Bay is characterized by several thousand ponds, which could be used for this 325 purpose. In contrast, WC batches always exhibited mortality, even when they were grown alone 326 in a tank or in a pond. Additionally, both origins exhibited mortality when a WC batch and HP 327 batches were grown together, although this phenomenon was only observed for one of the three 328 tanks in the laboratory (Figs. 4b and 5b). The small number of WC oysters used for this 329 condition combined with the low percentage of OsHV-1 infected animals at reception of the 330 batch could explain this result. Together, our results suggested that OsHV-1 was horizontally 331 transmitted from the WC batch to the HP batches in the mixed conditions in the laboratory and 332 pond, and this transmission occurred quickly because the mortality began at nearly the same time 333 in the various groups tested. This report is the first of such a transmission from naturally infected 334 wild-caught spat to naïve hatchery-produced spat. Our study provides new information on the 335 spread of the disease; to date, the horizontal transmission of OsHV-1 has only been demonstrated 336 from unselected and asymptomatic adults to naïve spat (Dégremont et al. 2013), and all other 337 studies have described the transmission of a homogenate prepared from infected oysters to larvae 338 (Le Deuff et al. 1994; Burge and Friedman 2012) or between healthy and experimentally infected 339 oysters under cohabitation conditions (Schikorski et al. 2011).

The mortality was higher for the WC1 batch at the mixed condition than for the separated 341 conditions in the pond and the laboratory, as well as for all batches in the mixed condition in the 342 pond and the laboratory in comparison to the field (Table 2). This finding confirmed that the 343 mortality related to OsHV-1 is more likely and intense in confinement than in an open 344 environment, as demonstrated by Garcia et al. (2011). Thus, the concentration of OsHV-1 345 particles could have been higher due to the small volume of the tank or the pond combined with 
346 the flow-through system, exceeding the threshold of resistance for some oysters in this condition 347 as shown by Dégremont et al. (2013).

OsHV-1 was detected in both WC batches from April 2010. Similar reports have been presented for numerous wild-caught batches (SMEL 2012). This finding suggests that the WC 350 batches were infected with OsHV-1 either in Marennes-Oléron Bay or Arcachon Bay during the 351 summer and fall of 2009. In both sites, the spawning season occurred during the summer 2009, 352 and the resulting larvae and spat could have been exposed to OsHV-1 particles and might have 353 been infected. Depending on the intensity of the viral challenge, a part of the cohorts might have 354 died due to OsHV-1 during the summer and fall of 2009, when the seawater temperature 355 exceeded $16^{\circ} \mathrm{C}$. Another group may have survived and remained asymptomatic carriers of the virus, and a last group might not have been in contact with the virus. Furthermore, our results 357 showed a higher mortality for the hatchery-produced batches than the wild-caught batches in the 358 field, as well as for the mixed condition in the pond and laboratory (Table 2). Even if a strong 359 genetic basis for mortality in juvenile C. gigas exists and the selected oysters were also resistant 360 to OsHV-1 (Dégremont et al. 2010a; Dégremont 2011), oysters of the WC batches are more 361 likely to be survivors of the primary infection in 2009. Thus, the WC and HP batches would 362 likely have exhibited comparable cumulative mortalities. To strengthen this hypothesis, 363 Dégremont et al. (2010b) showed that the survival rate of survivors was higher than in oysters 364 protected from the mortality risk factors.

The use of specific pathogen-free animals, such as the three HP batches for which OsHV1 was not detected at the beginning of the experiment, was advantageous over the use of wildcaught spat for growth in an area where the pathogen has not yet been introduced. Nevertheless, 368 the utilization of such animals in areas where the disease is present usually leads to massive 
mortality, such as that reported in the present study, but also in other oyster species, as

370 demonstrated for $C$. virginica with Perkinsus marinus and C. ariakensis with Bonamia ostreae

371 (Albright et al. 2007; Carnegie et al. 2008). Additionally, naïve WC spat would also benefit from

372 an OsHV-1-free environment; not just naïve HP spat, but all WC spat should be considered as

373 infected with OsHV-1, because the disease was detected in all areas where these animals are

374 caught in the wild in France. Extreme care should then be taken with these animals to prevent the

375 introduction of OsHV-1 into national and international pathogen-free areas, such as hatcheries,

376 nurseries, ponds, or open sites.

Moreover, management strategies exist to limit the spread of the disease, its intensity, and

378 the reservoir host. The mortality could be significantly reduced via selective breeding to improve

379 the OsHV-1 resistance, decrease the oyster mortality, reduce the reservoir host, and limit

380 horizontal transmission (Dégremont et al. 2010a; Dégremont 2011; Dégremont et al. 2013). This

381 approach can be easily implemented for hatchery production, as it is now broadly used by some

382 French commercial hatcheries. Establishing a control strategy for wild-caught spat remains more

383 difficult because the genetic background includes cultured and wild diploid oyster populations.

384 The development of a restoration program is one possibility that could help to introduce genetic

385 resistance in these populations via the production of numerous disease-resistant strains in

386 hatcheries, which would then be introduced in the field. Of course, such approaches require

387 particular considerations, such as (1) a massive introduction of disease-resistant oysters in

388 comparison to wild and cultured stocks at least several years in a row, (2) massive mortality due

389 to OsHV-1 each year to obtain a constant selective pressure on the oyster stocks, (3) the

390 significant reduction of the gene flow through the transfer of unselected oysters into the 391 environment and (4) the identification of the spatial and temporal variability of disease refuges, 
392 which would undeniably impact the development of resistance, as demonstrated in $C$. virginica 393 for MSX and Dermo (Ford et al. 2012). If these issues are not addressed, restoration programs 394 will have a limited impact, as demonstrated for C. virginica in the Yeocomico River (Carlsson et 395 al. 2008).

\section{CONCLUSIONS}

398 The results of our study indicated that French wild-caught spat are infected with OsHV-1 and 399 remain asymptomatic carriers until the environmental conditions favor the disease. The use of 400 such oysters allows the spread of the disease in disease-free areas or disease-free animals, 401 especially for unselected oysters. Unselected hatchery-produced spat could be protected from the 402 mortality due to OsHV-1 when they are grown separate from infected stock, and disease-free 403 water is used. Indeed, not using UV or using water pumped during a major mortality event in the 404 field could contaminate the HP oysters with OsHV-1. Importantly, the HP oysters were always 405 protected from the mortality risk factor in the present study, and care must be taken when oyster 406 farmers use such animals, as they may have been grown in an area where OsHV-1 is present.

408 Acknowledgments

409 We want to thank the hatchery, nursery, and genetic teams of the Laboratory Genetics and 410 Pathology, IFREMER La Tremblade and IFREMER Bouin, for their assistance in oyster 411 production, in particular Christophe Ledu, Max Nourry and Tanguy Guyader. This work was 
412 funded by the Contrat de Projet Etat Région Poitou-Charentes, 2007 - 2013, Convention 413 n008/RPC-A-29 du 19 mai 2008.

\section{LITERATURE CITED}

416 Albright BW, Abbe GR, McCollough CB, Barker LS, Dungan CF (2007) Growth and mortality of dermo-disease-free juvenile oysters (Crassostrea virginica) at three salinity regimes in an enzootic area of Chesapeake Bay. J Shellfish Res 26:451-463

Arzul I, Renault T, Thebault A, Gerard A (2002) Detection of oyster herpesvirus DNA and proteins in asymptomatic Crassostrea gigas adults. Virus Res 84:151-160

Burge CA, Friedman CS (2012) Quantifying Ostreid Herpesvirus (OsHV-1) Genome copies and expression during transmission. Microb Ecol 63:596-604

423 Cameron A, Crane M (2011) Final Report: OsHV-1 $\mu$ Var International Workshop, Cairns, Queensland, Australia 9-10 July 2011. AusVet Animal Health Services and Fisheries Research and Development Corporation, Canberra.

426 Carlsson J, Carnegie RB, Cordes JF, Hare MP, Leggett AT, Reece KS (2008) Evaluating recruitment contribution of a selectively bred aquaculture line of the oyster, Crassostrea virginica used in restoration efforts. J Shellfish Res 27:1117-1124

429 Carnegie RB, Stokes NA, Audemard C, Bishop MJ, Wilbur AE, Alphin TD, Posey MH, Peterson 430 $\mathrm{CH}$, Burreson EM (2008) Strong seasonality of Bonamia sp infection and induced Crassostrea ariakensis mortality in Bogue and Masonboro Sounds, North Carolina, USA. J Invertebr Pathol 98:335-343 
Dégremont L (2011) Evidence of herpesvirus (OsHV-1) resistance in juvenile Crassostrea gigas selected for high resistance to the summer mortality phenomenon. Aquaculture 317:94-98

Dégremont L (2013) Size and genotype affect resistance to mortality caused by OsHV-1 in Crassostrea gigas. Aquaculture 416-417:129-134

Dégremont L, Bédier E, Boudry P (2010a) Summer mortality of hatchery-produced Pacific oyster spat (Crassostrea gigas). II. Response to selection for survival and its influence on growth and yield. Aquaculture 299:21-29

Dégremont L, Boudry P, Ropert M, Samain J-F, Bédier E, Soletchnik P (2010b) Effects of age and environment on survival of summer mortality by two selected groups of the Pacific oyster Crassostrea gigas. Aquaculture 299:44-50

Dégremont L, Guyader T, Tourbiez D, Pépin JF (2013) Is horizontal transmission of the Ostreid herpervirus OsHV-1 in Crassostrea gigas affected by unselected or selected survival status in adults to juveniles. Aquaculture 408-409:51-57

Dégremont L, Soletchnick P, Boudry P (2010c) Summer mortality of selected juvenile Pacific oyster Crassostrea gigas under laboratory conditions and comparison with field performance. J Shellfish Res 29:847-856

Dundon WG, Arzul I, Omnes E, Robert M, Magnabosco C, Zambon M, Gennari L, Toffan A, Terregino C, Capua I, Arcangeli G (2011) Detection of Type 1 Ostreid Herpes variant (OsHV-1 $\mu$ var) with no associated mortality in French-origin Pacific cupped oyster Crassostrea gigas farmed in Italy. Aquaculture 314:49-52 
453

454

455

456

457

458

459

460

461

462

463

464

465

466
EFSA (2010). Scientific Opinion on the increased mortality events in Pacific oysters, Crassostrea gigas. EFSA J 8:1894-1953

Ford S, Scarpa E, Bushek D (2012) Spatial and temporal variability of disease refuges in an estuary: Implications for the development of resistance. J Mar Res 70:253-277

Garcia C, Thébault A, Dégremont L, Arzul I, Miossec L, Robert M, Chollet B, Francois C, Joly J-P, Ferrand S, Kerdudou N, Renault T (2011) Ostreid herpesvirus 1 detection and relationship with Crassostrea gigas spat mortality in France between 1998 and 2006. Vet Res 42:73

Goulletquer P, Le Moine O (2002) Shellfish farming and coastal zone management (CZM) development in the Marennes-Oleron Bay and Charentais Sounds (Charente Maritime, France): A review of recent developments. Aquacult Int 10:507-525

Guichard B, François C, Joly JP, Garcia C, Saulnier D, Pépin JF, Arzul I, Ommes E, Tourbiez D, Faury N, Haffner P, Chollet B, Robert M, Renault T (2011) Bilan 2010 du réseau REPAMO. Rapport IFREMER 22p

Jenkins C, Hick P, Gabor M, Spiers Z, Fell S, Gu X, Read A, Go J, Dove M, O'Connor W, Kirkland P, Frances J (2013) Identification and characterisation of an ostreid herpesvirus1 microvariant (OsHV-1 $\mu$-var) in Crassostrea gigas (Pacific oysters) in Australia. Dis Aquat Organ 105:109-126

Lacoste A, Jalabert F, Malham S, Cueff A, Gelebart F, Cordevant C, Lange M (2001) A Vibrio splendidus strain is associated with summer mortality of juvenile oysters Crassostrea gigas in the Bay of Morlaix (North Brittany, France). Dis Aquat Organ 46:139-145. 
474 Le Roux F, Gay M, Lambert C, Waechter M, Poubalanne S, Chollet B, Nicolas JL, Berthe F 475 (2002) Comparative analysis of Vibrio splendidus-related strains isolated during Crassostrea gigas mortality events. Aquat Living Resour 15:251-258.

477 Le Deuff R-M, Nicolas J-L, Renault T, Cochennec N (1994) Experimental transmission of a Herpes-like virus to axenic larvae of Pacific oyster, Crassostrea gigas. Bull Eur Ass Fish Pathol 14:69-72 among hatchery-reared larval Pacific oyster Crassostrea gigas. Dis Aquat Organ 24:149157.

Littell RC, Stroup WW, Freund RJ (2002) SAS ${ }^{\circledR}$ for Linear Models. 4th ed. Cary, NC:SAS Institute Inc

Lynch SA, Carlsson J, Reilly AO, Cotter E, Culloty S.C (2012) A previously undescribed ostreid herpes virus 1 (OsHV-1) genotype detected in the pacific oyster, Crassostrea gigas, in Ireland. Parasitol 139:1526-1532

Martenot C, Fourour S, Oden E, Jouaux A, Travaille E, Malas JP, Houssin M (2012) Detection of the OsHV-1 $\mu$ Var in the Pacific oyster Crassostrea gigas before 2008 in France and description of two new microvariants of the Ostreid Herpesvirus 1 (OsHV-1). Aquaculture 338:293-296

Oden E, Martenot C, Berthaux M, Travaille E, Malas JP, Houssin M (2011) Quantification of ostreid herpesvirus 1 (OsHV-1) in Crassostrea gigas by real-time PCR: Determination of a viral load threshold to prevent summer mortalities. Aquaculture 317:27-31 
495

496

497

498

499

500

501

502
Paul-Pont I, Dhand N, Whittington R (2013) Influence of husbandry practices on OsHV-1 associated mortality of Pacific oysters Crassostrea gigas. Aquaculture 412-413:202-214

Peeler EJ, Allan Reese R, Cheslett DL, Geoghegan F, Power A, Thrush MA (2012) Investigation of mortality in Pacific oysters associated with Ostreid herpesvirus- $1 \mu$ Var in the Republic of Ireland in 2009. Prev Vet Med 105:136-143

Pépin JF, Riou A, Renault T (2008) Rapid and sensitive detection of ostreid herpesvirus 1 in oyster samples by real-time PCR. J Virol Methods 149:269-276

Pernet F, Barret J, Le Gall P, Corporeau C, Dégremont L, Lagarde F, Pépin JF, Keck N (2012) Mass mortalities of Pacific oysters Crassostrea gigas reflect infectious diseases and vary with farming practices in the Mediterranean Thau lagoon, France. Aquacult Env Interac $2: 215-237$

Petton B, Pernet F, Robert R, Boudry P (2013) Temperature influence on pathogen transmission and subsequent mortalities in juvenile Pacific oysters Crassostrea gigas. Aquacult Env Interac 3:257-273

Renault T, Le Deuff RM, Chollet B, Cochennec N, Gerard A (2000) Concomitant herpes-like virus infections in hatchery-reared larvae and nursery-cultured spat Crassostrea gigas and Ostrea edulis. Dis Aquat Organ 42:173-183

Rohfritsch A, Bierne N, Boudry P, Heurtebise S, Cornette F, Lapègue S (2013) Population genomics shed light on the demographic and adaptive histories of European invasion in the Pacific oyster, Crassostrea gigas. Evol Appl 6:1064-1078 
515 Roque A, Carrasco N, Andree KB, Lacuesta B, Elandaloussi L, Gairin I, Rodgers CJ, Furones 516 MD (2012) First report of OsHV-1 microvar in Pacific oyster (Crassostrea gigas) $517 \quad$ cultured in Spain. Aquaculture 324:303-306

518 Sauvage C, Pépin JF, Lapègue S, Boudry $\mathrm{P}$, Renault $\mathrm{T}$ (2009) Ostreid herpes virus 1 infection in 519 families of the Pacific oyster, Crassostrea gigas, during a summer mortality outbreak: 520 Differences in viral DNA detection and quantification using real-time PCR. Virus Res $142: 181-187$

522 Schikorski D, Faury N, Pepin JF, Saulnier D, Tourbiez D, Renault T (2011) Experimental ostreid 523 herpesvirus 1 infection of the Pacific oyster Crassostrea gigas: Kinetics of virus DNA detection by q-PCR in seawater and in oyster samples. Virus Res 155:28-34

Segarra A, Pépin JF, Arzul I, Morga B, Faury N, Renault T (2010) Detection and description of a particular Ostreid herpesvirus 1 genotype associated with massive mortality outbreaks of Pacific oysters, Crassostrea gigas, in France in 2008. Virus Res 153:92-99

SMEL (2012) Suivi Sentinelle Interrégional. Bulletin nº 5. Syndicat Mixte pour l’Equipement du Littoral. http://www.smel.fr/iso_album/bulletin_5_interegional.pdf 


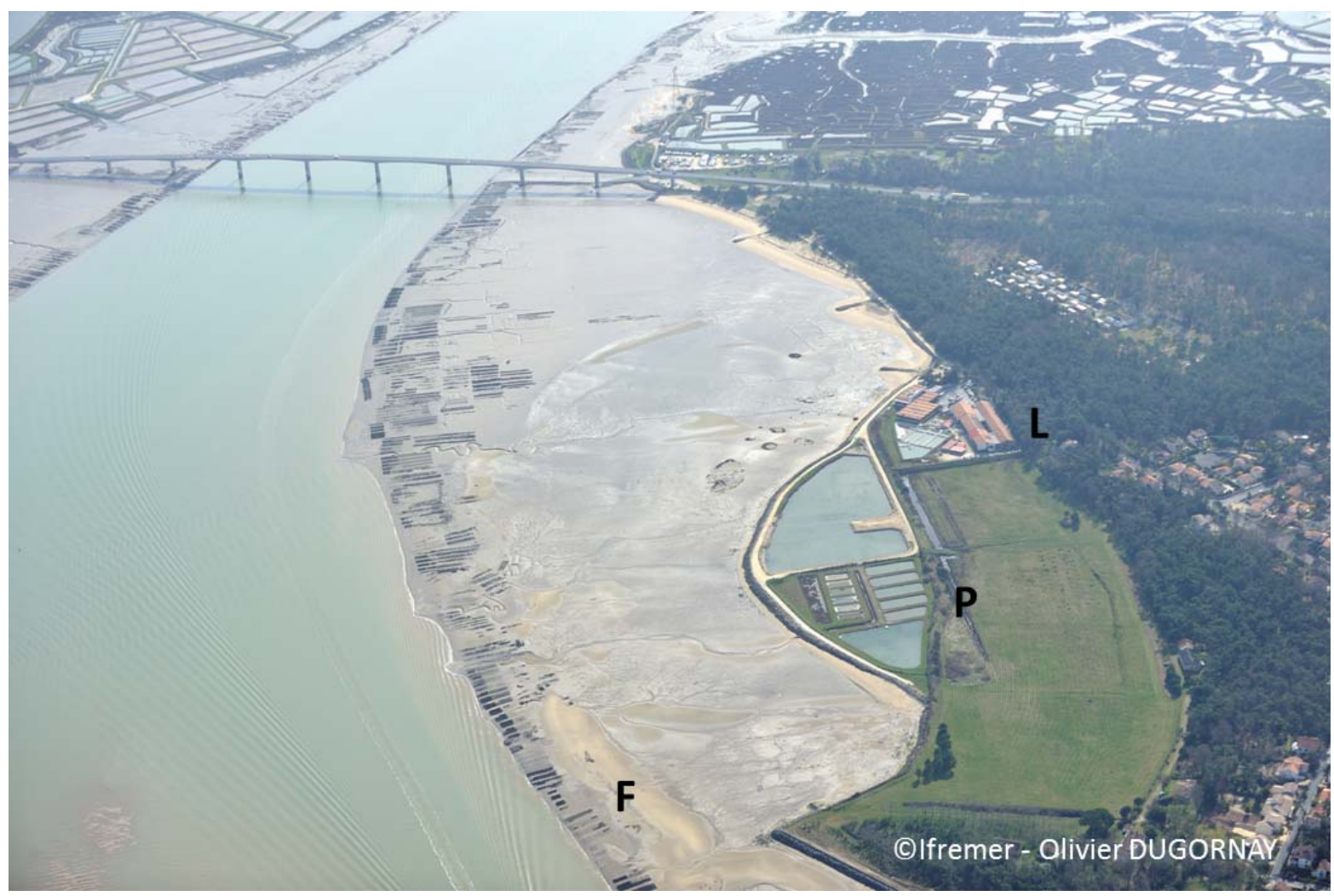

534 Fig. 1. Location of the three sites (F field, P ponds, L laboratory) on the Seudre River, Marennes535 Oléron Bay, France 


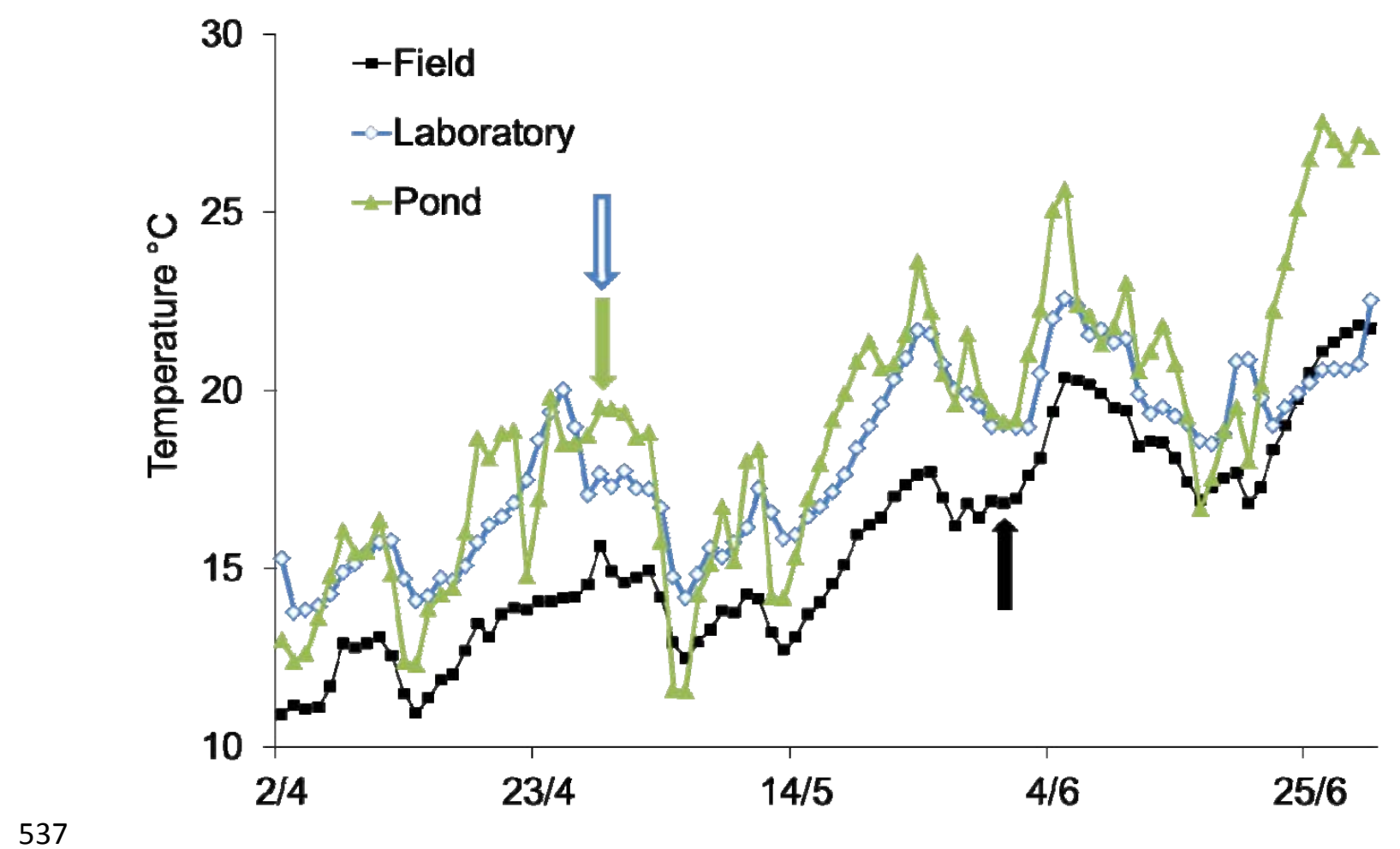

538 Fig. 2. Seawater temperature $\left({ }^{\circ} \mathrm{C}\right)$ at the three sites throughout the experiment. The arrows 539 indicate the onset of a significant mortality event. 


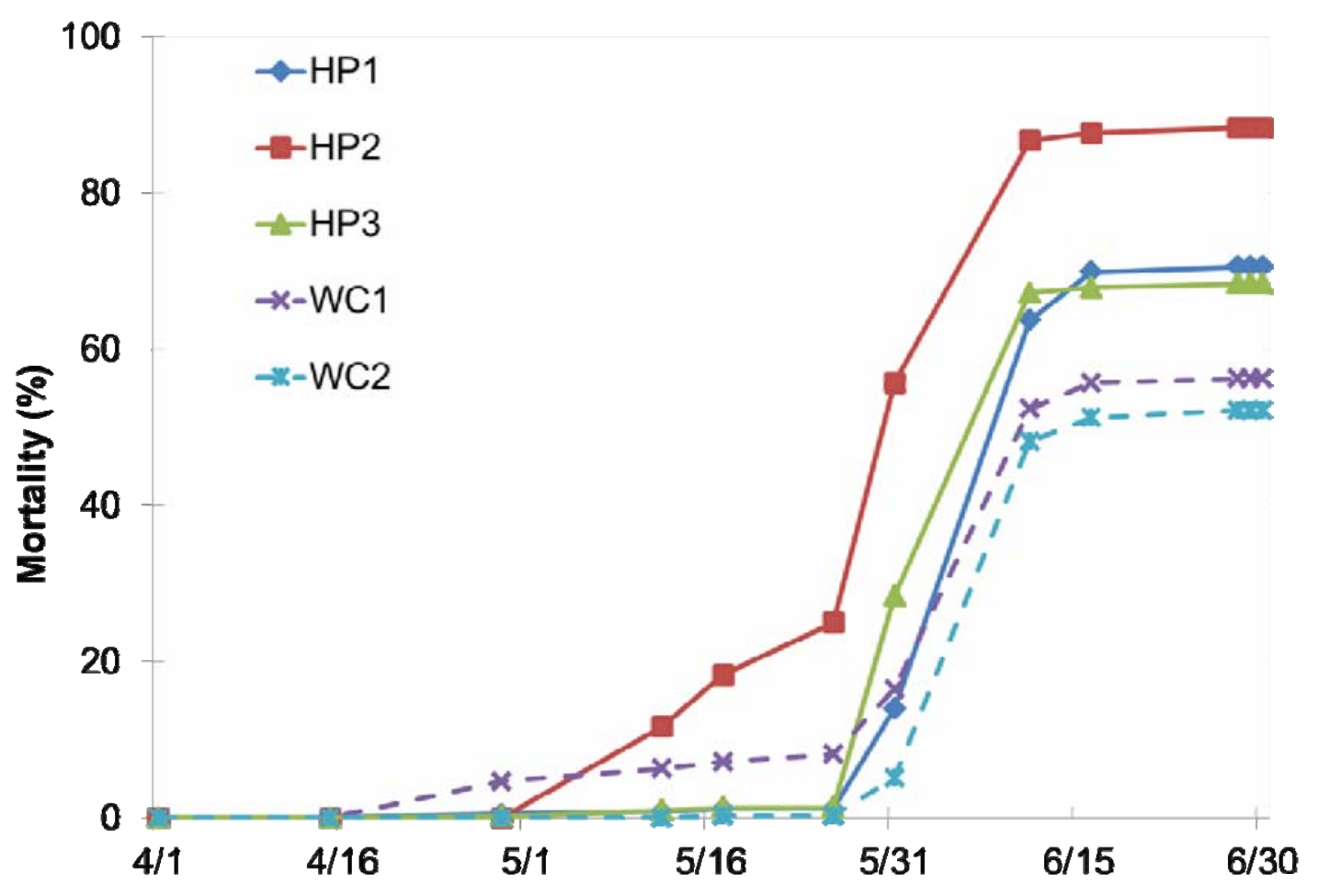

542 Fig. 3. Kinetics of the mortality for the three hatchery-produced batches (HP1 to HP3, solid lines)

543 and the two wild-caught batches (WC1 and WC2, dashed lines) in the field from April to June 5442010. 

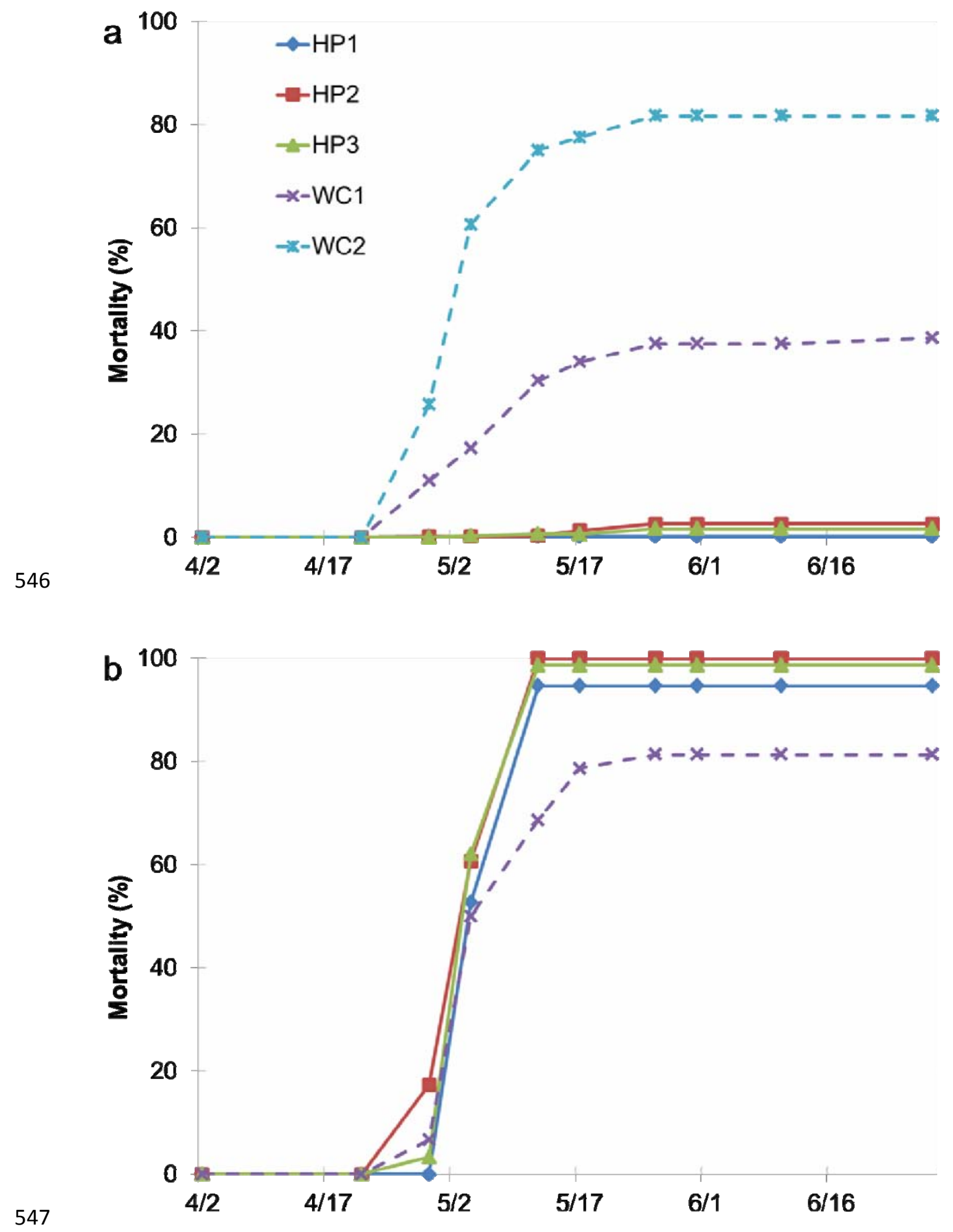
548 Fig. 4. Kinetics of the mortality for the three hatchery-produced batches (HP1 to HP3, solid lines)

549 and the two wild-caught batches (WC1 and WC2, dashed lines) in the pond from April to June 5502010 for the separated (a) and mixed conditions (b). 

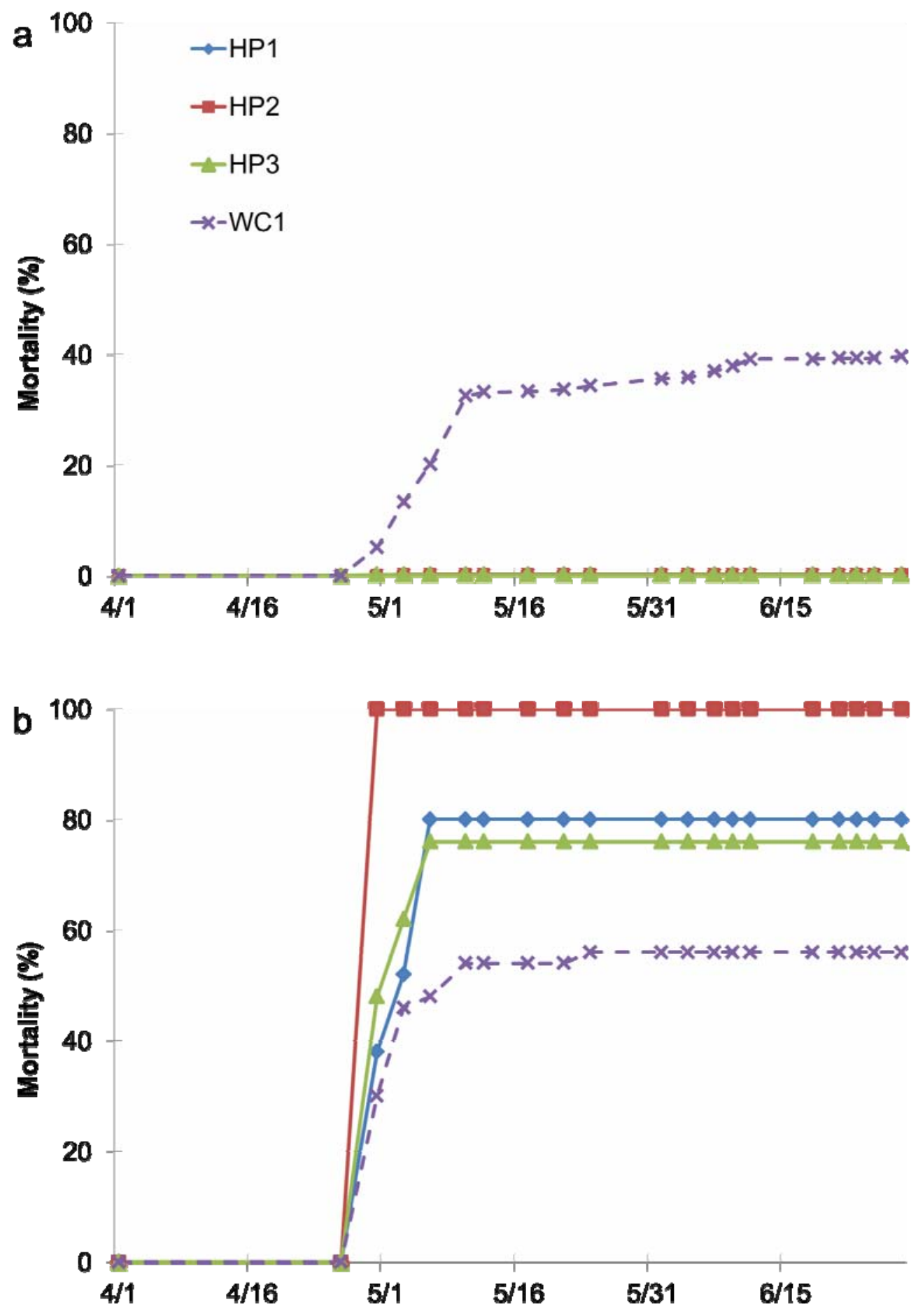

554 Fig. 5. Kinetics of the mortality for the three hatchery-produced batches (HP1 to HP3, solid lines) 555 and the wild-caught batch WC1 (dashed line) in the laboratory from April to June 2010 for the 
556 separated (a) and mixed conditions (b). For the latter, the graph only shows the kinetics of the 557 mortality in the tank where mortality was observed. 
558 Table 1. Summary of the batches and conditions tested

\begin{tabular}{|c|c|c|c|c|}
\hline Site & Condition $^{\mathrm{a}}$ & Batch tested & $\begin{array}{l}\text { Number of } \\
\text { replicates } \\
\text { per batch }\end{array}$ & $\begin{array}{c}\text { Number of } \\
\text { oysters per } \\
\text { replicate }\end{array}$ \\
\hline Field $^{\mathrm{b}}$ & Mixed & $\begin{array}{c}\text { HP1, HP2, HP3, } \\
\text { WC1, WC2 }\end{array}$ & 3 bags & 200 \\
\hline \multirow[t]{2}{*}{ Pond } & Separated & $\begin{array}{c}\text { HP1, HP2, HP3, } \\
\text { WC1, WC2 }\end{array}$ & 3 bags & 200 \\
\hline & Mixed & $\begin{array}{c}\text { HP1, HP2, HP3, } \\
\text { WC1 }\end{array}$ & 3 bags & 50 \\
\hline Laboratory & Separated & $\begin{array}{c}\text { HP1, HP2, HP3, } \\
\text { WC1 }\end{array}$ & 3 tanks & 200 \\
\hline & Mixed & $\begin{array}{c}\text { HP1, HP2, HP3, } \\
\text { WC1 }\end{array}$ & 3 tanks & 50 \\
\hline
\end{tabular}

559 a "Separated" indicates that only one batch was placed in the pond or tank, i.e. within-batch 560 cohabitation trial, while "mixed" means that all batches were placed in the pond or tank, i.e. 561 between-batches cohabitation trials. 
$562{ }^{b}$ the separated condition was not tested because the batches could not be physically separated in 563 the field condition. 
565 Table 2. Cumulative mortality (\%) (mean and standard deviation among the replicates) of each

566 batch in each condition and each site on June 30th

\begin{tabular}{|c|c|c|c|c|}
\hline Condition & Batch & Laboratory $^{\mathrm{a}}$ & Pond & Field \\
\hline \multirow[t]{5}{*}{ Mixed } & HP1 & $27 \pm 46$ & $95 \pm 9$ & $71 \pm 4$ \\
\hline & HP2 & $33 \pm 26$ & $100 \pm 0$ & $88 \pm 9$ \\
\hline & HP3 & $26 \pm 43$ & $98 \pm 2$ & $68 \pm 23$ \\
\hline & WC1 & $19 \pm 32$ & $81 \pm 16$ & $56 \pm 4$ \\
\hline & WC2 & & & $52 \pm 7$ \\
\hline \multirow[t]{5}{*}{ Separated } & HP1 & $0 \pm 0$ & $1 \pm 1$ & \\
\hline & HP2 & $1 \pm 1$ & $3 \pm 2$ & \\
\hline & HP3 & $1 \pm 1$ & $2 \pm 1$ & \\
\hline & WC1 & $40 \pm 2$ & $39 \pm 40$ & \\
\hline & WC2 & & $82 \pm 1$ & \\
\hline
\end{tabular}

$567{ }^{\mathrm{a}}$ To obtain the mortality rates for the tank representing the mixed condition for which a mortality 568 outbreak was observed, the mortality rates should be multiplied by 3. 
570 Table 3. Number of detected positive for OsHV-1 screening in living animals for each batch in

571 each condition and each site on June 30th

\begin{tabular}{|c|c|c|c|c|c|}
\hline \multirow[b]{2}{*}{ Condition } & \multirow[b]{2}{*}{ Batch } & \multirow[b]{2}{*}{ at deployment } & \multicolumn{3}{|c|}{ Endpoint } \\
\hline & & & Laboratory $^{\mathrm{a}}$ & Pond & Field \\
\hline \multirow[t]{5}{*}{ Mixed } & HP1 & $0 / 50$ & $0 / 12-0 / 12$ & $0 / 5$ & $3 / 12$ \\
\hline & HP2 & $0 / 50$ & 0/12-ad & ad & $4 / 12$ \\
\hline & HP3 & $0 / 50$ & $0 / 12-2 / 6$ & $0 / 1$ & $7 / 12$ \\
\hline & WC1 & $7 / 50$ & 0/12-1/12 & $0 / 12$ & $1 / 12$ \\
\hline & WC2 & $1 / 50$ & & & $2 / 12$ \\
\hline \multirow[t]{5}{*}{ Separated } & HP1 & & $0 / 12$ & $0 / 12$ & \\
\hline & HP2 & & $0 / 12$ & $0 / 12$ & \\
\hline & HP3 & & $0 / 12$ & $0 / 12$ & \\
\hline & WC1 & & $0 / 12$ & $0 / 12$ & \\
\hline & WC2 & & & $1 / 12$ & \\
\hline
\end{tabular}

$572 \quad{ }^{a}$ first number is given for the replicates without mortality, and the second numbers for the

573 replicate with mortality.

574 ad: all dead. 